\title{
The Model OF Degressive TAXation OF TruCKS: Case of The Czech Republic
}

\author{
Břetislav Andrlík ${ }^{1}$, Michaela Podlasová ${ }^{2}$
}

\begin{abstract}
The article examines issues related to the design of road tax as an instrument supporting the operation of trucks that are more environment-friendly to the transport infrastructure. The Introduction presents analyses of road taxation in the European Union Member States, whose aim was to identify features supporting trucks that are eco-friendly with regard to the infrastructure. The principal part of the contribution is the formulation of a regression model of road tax rates, which is subjected to statistical, econometric and economic verification in order to confirm or disprove degressivity of road tax rates for trucks. The economic verification is based on typical examples of vehicles defined in Annex 2 to the text. The Conclusion presents the results achieved, which verify the degressive nature of road tax in the Czech Republic. The tax rates are degressive in relation to the number of truck axles; therefore, a proposal for the elimination of degressivity in the system of tax rates for trucks was designed based on the principle of fair taxation, which is also discussed in the contribution.
\end{abstract}

\section{Keywords}

Road Tax, Truck, Tax Rate, Degressivity, Transport Infrastructure

\section{Introduction}

The taxation of road motor vehicles was introduced in most OECD countries in the first half of the 20th century and has become an important source of tax revenues for most governments. The system of road motor vehicle taxation in the broadest sense includes the application of a wide range of excise duties, such as VAT, specific and ad valorem taxes (OECD, 2016). Taxes on the operation of trucks include regular payments collected as compensation for the utilization of public infrastructure, most frequently in the form of road tax, which is confirmed by Borger, Mayeres (2007). According to

\footnotetext{
${ }^{1}$ Mendel University in Brno, Faculty of Business and Economics, Zemědělská 1, 61300 Brno, Czech Republic. E-mail: xandrlik@mendelu.cz.

${ }^{2}$ Mendel University in Brno, Faculty of Business and Economics, Zemědělská 1, 61300 Brno, Czech Republic. E-mail: xpodlasov@node.mendelu.cz
} 
Cnossen (2005), the payments for the utilization of infrastructure should be determined at such rates so as to cover the total costs of operation and maintenance of the road network. According to Smith (1958), the principle of fair taxation is the fundamental attribute of a good tax system. From the point of fair taxation, road tax is an example of the benefit principle, which is also affirmed by Vančurová, Láchová, Vítková (2016) or Široký (2003). However, in recent years, negative externalities have been discussed in connection with road tax, and thus it has been classified as one of selective excise duties (environmental taxes). As pointed out by Delucchi (2003), negative externalities are undesirable from the economic point of view, because when they exist, originators of damage are allowed to make decisions that lead to the situation where social costs exceed revenues. The assessment of environmental tax impacts in different countries, the Czech Republic being one of them, is dealt with by Štreimikiene (2015), who inter alia examines the share of environmental tax receipts in the GDP. From the point of classification of environmental taxes according to their objectives, Andrlík, Ptáčková Mísařová, Vrtalová (2014), Kubátová (2015) or Zimmermannová (2016) suggest that it is one of incentiveenhancing taxes, serving to influence the behaviour of taxpayers in order to reduce the production of negative externalities - harmful substances. The issue of internalization of external air pollution costs is addressed in detail by Štreimikienè and Ališauskaitè-Šeškienè (2016).

From the point of road tax applied as compensation for the use of public infrastructure, there is a common feature in the EU Member States, consisting in different amounts of tax liability directly related to the type of truck suspension. Such principle of tax assessment is applied in Belgium, Bulgaria, Denmark, Estonia, France, Cyprus, Lithuania, Latvia, Luxembourg, Malta, the Netherlands, Portugal, the United Kingdom, but also in Italy, where the percentage of tax rate is reduced in case the truck is equipped with air suspension of the chassis (ACEA, 2019). Annual tax rates for such trucks are assessed differently in these countries; if compared with other trucks, their levels are lower or even zero. In certain countries, e.g. in the Netherlands, the different taxation of trucks with air and other suspension systems is applied from a certain level of permissible maximum weight. On the other hand, trucks with air suspension below a certain level of permissible maximum weight are tax exempt in Belgium, Denmark and Estonia. The undoubted objective of such tax rates is to favour trucks that are more environmentally friendly to the infrastructure (i.e. trucks equipped with air suspension).

Section 6 (2) of Act No. 16/1993 Coll., on Road Tax, as amended (hereinafter referred to as "ART") clearly suggests that trucks in the Czech Republic are not taxed in a way that favours vehicles that are environmentally friendly in terms of infrastructure wear. The only two criteria of assessing the annual tax rate are the number of axles and the permissible maximum weight (Marková, 2019), as seen in the table listing annual tax rates. More detailed examination of road tax rates reveals that they are degressive in terms of number of axles: a truck with a higher number of axles is subject to less tax than a truck with a lower number of axles while the weight is identical. Degressive tax rate means that with the growing tax base, the rate decreases. David and Andrlík (2020) deal in detail with degressivity in the field of trucks, and they also evaluate the distorting parameters 
of the road tax in the Czech Republic where the degree and construction of the tax rate causes degressivity. According to Schultzová et al. (2018) and Široký (2008), this is a rare situation in tax systems. Therefore, tax rates determined in this way must serve some other than primarily fiscal purpose. The subject of this contribution is to formulate a regression model of road tax on trucks applied in the Czech Republic, to confirm the degressive nature of the tax rates determined in the Czech Republic while using statistical, econometric and economic verification, and to identify the "green" feature supporting multi-axle trucks, whose operation is more sensitive to the transport infrastructure.

\section{Materials and methods}

\section{Methodology and design of a regression model of road tax for trucks}

Verification of tax rate degressivity will be carried out using the multidimensional regression analysis described by Hindls et al. (2007), selected independent variables $X_{1}$ (number of axles) and $X_{2}$ (permissible maximum weight) per dependent variable $Y$ (annual tax rate) by OLS method (ordinary least squares). In order to model the dependence between independent variables and a dependent variable, the method of sequential selection of regressors, particularly its variant referred to as degressive selection, described by Cipra (2013), will be used. The first step in the sequential selection of regressors is the design of a model in which all explanatory variables are contained, i.e. the variables such as a number of axles and permissible maximum weight. For initial estimation of parameters by OLS method, the straight-line model with the functional form described by Hušek (2007) was selected. For testing purposes, 5\% significance level was selected. The results of the initial straight-line models can be seen in (Table 1).

Table 1: Initial regression straight line model

\begin{tabular}{|l|c|c|c|cc|}
\hline Variable & Coefficient $\left(\beta_{j}\right)$ & Standard error & t-test & p-value & \\
\hline Constant & 5930.39 & 1565.32 & 3.789 & 0.0005 & $* * *$ \\
\hline Number of axles & -3964.05 & 727.26 & -5.451 & $2.61 e^{-06}$ & $* * *$ \\
\hline Permissible maximum weight & 1364.78 & 70.65 & 19.32 & $3.34 e^{-022}$ & $* * *$ \\
\hline
\end{tabular}

\begin{tabular}{|l|l|}
\hline Determination coefficient & 0.914668 \\
\hline Adjusted determination coefficient & 0.910506 \\
\hline $\mathrm{F}(2.41)$ & 219.7387 \\
\hline P-value (F) & $1.22 e^{-22}$ \\
\hline$r_{X_{1} X_{2}}=r_{X_{2} X_{1}}$ & 0.6146 \\
\hline
\end{tabular}

Source: Gretl, own calculation

Before subsequent modification of the initial straight-line model, it is necessary to verify if the data is not affected by the issue of collinearity. The issue of collinearity, i.e. the dependence between two explanatory variables, is indicated, at a glance, by the high value of determination coefficient accompanied by a large number of insignificant variables. 
The determination coefficient in the initial model takes the value of $R^{2}=0,914668$ (the model explained $91.47 \%$ of the dependent variable variability), nevertheless, all independent variables are significant (their p-values are lower than the selected significance level $\alpha=0.05$ ), which means that the collinearity should not make bigger problems in this case. The above-mentioned can also be verified by means of paired correlation coefficients, principal component method or VIF method (factor analysis) described by Hušek (2007). The calculated paired correlation coefficient of the variable $X_{1}$ and $X_{2}\left(r_{X_{1} X_{2}}=r_{X_{2} X_{1}}=0,6146\right)$ is lower than 0.8 , which is a reference value referring to the issue of collinearity, i.e. the dependence of two independent variables. In the case of VIF method, the issue of collinearity is referred to by $\operatorname{VIF}\left(\beta_{j}\right)>10$. In this initial straight-line model, however, the calculated VIF variable value is $X_{1}=1.607$, as well as the VIF variable value is $X_{2}=1.607$. This method did not discover the issue of collinearity either.

Figure 1: Straight line model residuals versus number of axles

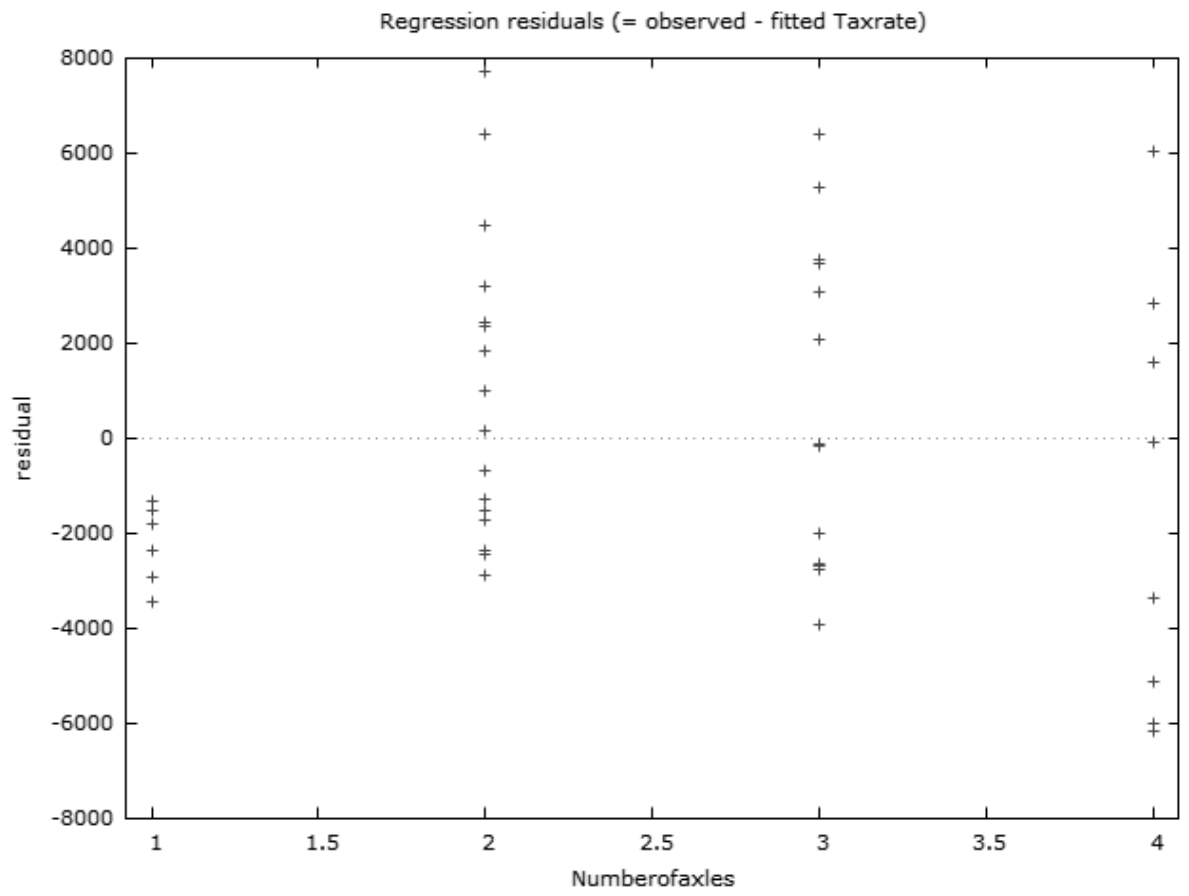

Source: Gretl, own calculation

Now, it is possible to go to reduction of the model with insignificant variable as it was proved that the data were not affected by the issue of collinearity. To test the insignificance of individual parameters of the model (i.e. the constant of variable $X_{1}$ and $X_{2}$ ), regression parameter significance tests (t-test) where hypotheses in econometric practice are formulated most frequently as follows: $H_{0}=$ the parameter is statistically insignificant, $H_{1}=$ the parameter is statistically significant (Cipra, 2013). In initial 
estimation, all independent variables, i.e. constant, variable $X_{1}$ and variable $X_{2}$ have a p-value $\left(\beta_{0}=0.0005, \beta_{1}=2.61 e^{-06}, \beta_{2}=3.34 e^{-022}\right)$ lower than the selected significance level for the purpose of testing hypotheses $(\alpha=0.05)$ and that is why we reject the zero hypotheses on statistical insignificance of parameters. All independent variables are statistically significant and will be left in the model henceforth. To determine a suitable functional form that would lead to a better explanation of the variability of an independent variable by dependent variables, it is possible to use the residual graphs of independent variables $X_{1}$ and $X_{2}$ in the straight-line model (Hušek, 2007).

The residuals of the independent variable $X_{1}$ do not cluster into any functional form that would be omitted in the model. Consequently, we leave the independent variable $X_{1}$ in the initial model in the same form of straight line.

\section{Figure 2: Straight line model residuals versus permissible maximum weight}

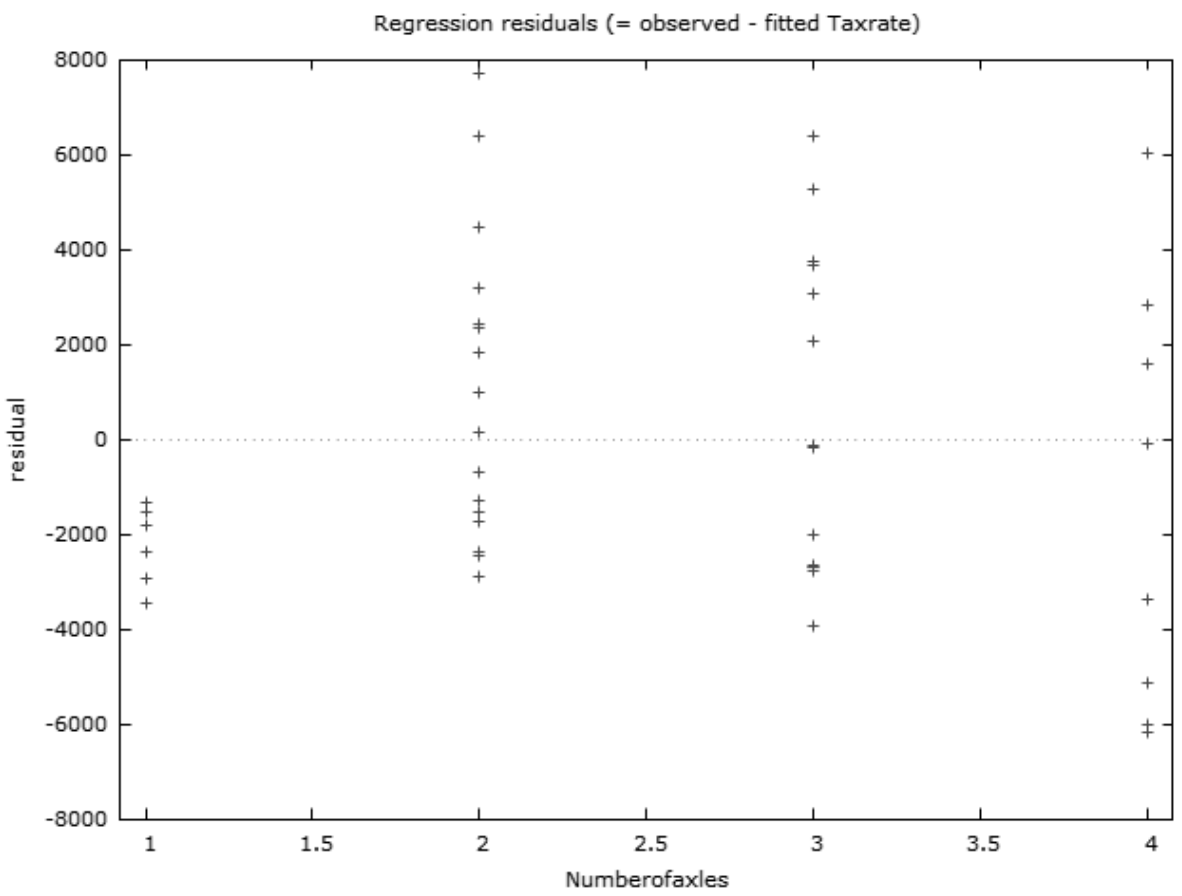

Source: Gretl, own calculation

In the case of independent variable $X_{2}$ (permissible maximum weight), the line model residuals cluster into the parabola shape which was omitted in the line model. The result, in the form of completion of the 2 nd degree polynomial of the independent variable $X_{2}$ (permissible maximum weight) into the initial straight-line model can be seen in (Table 2). The inclusion of the 2nd degree polynomial of the independent variable $X_{2}$ in the initial line model should result in an increase of the determination coefficient. 
Table 2: Regression model completed with a 2nd degree polynomial in variable $X_{2}$

\begin{tabular}{|l|c|c|c|cc|}
\hline Variable & Coefficient $\left(\beta_{j}\right)$ & Standard error & t-test & p-value & \\
\hline Constant & 8369.13 & 1676.89 & 4.991 & $1.22 e^{-05}$ & $* * *$ \\
\hline Number of axles & -3954.80 & 670.88 & -5.895 & $6.64 e^{-07}$ & $* * *$ \\
\hline Permissible maximum weight & 848.59 & 191.867 & 4.423 & $7.29 e^{-05}$ & $* * *$ \\
\hline Sq_Permissible maximum weight & 16.39 & 5.73 & 2.860 & $0.0067 \quad * * *$ \\
\hline Determination coefficient & & & 0.929158 \\
\hline Adjusted determination coefficient & & & 0.923845 \\
\hline F (2.41) & & & 174.8793 \\
\hline P-value (F) & $5.03 e^{-23}$ \\
\hline
\end{tabular}

Source: Gretl, own calculation

The resultant linear regression model with the 2 nd degree polynomial has explained $92.91 \%$ of the variability of the dependent variable. In comparison with the linear straightline regression model that has explained $91.47 \%$ of the variability of dependent variable, there was some improvement. The sign of the independent variable parameter $X_{1}$ is negative $\left(\beta_{1}=-3954.80\right)$, i.e. the model confirmed the above-mentioned statement about the degressive determination of annual tax rates in terms of number of truck axles. The regression equation of the resultant model for determination of the road tax rate has the following form:

$$
\hat{Y}=8369.13-3954.80 * X_{1}+848.60 * X_{2}+16.4+X_{2}^{2}
$$

where:

$X_{1}=$ Number of axles,

$X_{2}=$ Permissible maximum weight in tons.

The resultant model with the 2 nd degree polynomial of the independent variable $X_{2}$ needs to be subject to econometric tests that verify classical linear assumptions - econometric verification. Only after these assumptions are met, the estimation of regression parameters by OLS method can be considered as best possible. Assumptions of the classical linear regression model are as follows: (Cipra, 2013):

* the regression model is linear in parameters, it contains the level constant, it is specified correctly and has an additively connected error term,

* the error term has a zero-average value,

* all independent variables are not correlated with the error term,

* observations of the error term are not correlated with each other,

* the error term has a constant variance (homoscedasticity of error term),

* no linear independent variable is a linear combination of another independent variable,

* the error term has a normal distribution. 
For testing the first assumption, i.e. the model is linear in parameters, it contains a level constant (in our case $\beta_{0}=8369.13$ ), is specified correctly and has an additively connected error term, it is possible to use the results in Table 2. Specifically, it is the parameter significance $t$-test of the resultant model ( $p$-value of individual independent variables of the model) and the F-test of overall significance of the model (P-value (F)).

As stated above, in the case of t-test, the hypotheses are formulated as follows: $H_{0}=$ the parameter is statistically insignificant, $H_{1}=$ the parameter is statistically significant. All parameters of the independent variables remained significant after the second-degree polynomial was added. Their $\mathrm{p}$-value $\left(\beta_{0}=1.22 e^{-05}, \beta_{1}=6.64 e^{-07}, \beta_{2}=7.29 e^{-05}\right.$, $\beta_{3}=0.0067$ ) assumes the values lower than $\alpha=0.05$, that is why we reject the zero hypothesis about their insignificance.

The same ways as in the case of t-tests of individual parameters of the model, the hypotheses are formulated equally also in the case of F-test that tests the significance of the entire model. The resultant $\mathrm{p}$-value $\left(p=5.03 e^{-23}\right)$ is lower than $\alpha=0.05$ therefore we reject the hypothesis about statistical significance of the model as well. So, it is possible to state that the parameters and the model itself are statistically insignificant, i.e. the model is statistically verified.

For verification of correct specification, which is another condition for fulfilment of the first assumption of the classical linear regression model, it is possible to use RESET and LM specification tests. These tests diagnose the specification errors that came into existence owing to omission of substantial variables or erroneous functional form of the model (Hušek, 2007). In the case of these tests, hypotheses are formulated positively, i.e.: $H_{0}=$ the model is specified correctly, $H_{1}=$ the model is specified incorrectly. Conversely, the goal is the $\mathrm{p}$-value higher than the selected significance level $(\alpha=0.05)$.

Table 3: Linear regression specification tests

\begin{tabular}{|l|l|l|}
\hline Specification tests & Test variant & p-value \\
\hline \multirow{3}{*}{ RESET test } & Squared and cubed powers & $9.47 e^{-016}$ \\
& Squared powers only & $1.27 e^{-007}$ \\
& Cubed powers only & 0.0021 \\
\hline \multirow{2}{*}{ LM test } & Squared powers & 0.0022 \\
& Logarithms & 0.0014 \\
\hline
\end{tabular}

Source: Gretl, own calculation

Based on the specification test results, we reject the zero hypothesis about correct specification of the model since the p-values of specification tests presented in Table 3 assume lower values than the selected significance level $\alpha=0.05$. The results show that the model with the 2 nd degree polynomial is undersized since the variability of the independent variable is only explained by independent variables $X_{1}$ and $X_{2}$, so besides the two independent variables, the amount of annual road tax rates is explained by other variables which are unknown at the first glance. Since the objective was to explain the amount of 
annual road tax with the use of the two independent variables $\left(X_{1}\right.$ and $\left.X_{2}\right)$, the results of specification tests cannot be evaluated negatively (Hušek, 2007). Another reason for rejection of the null hypothesis may consist in a low number of values (road tax rate), which implies that every little variation may affect the test results. Similarly, a high percentage of explanation of the variability in the independent variable, $R^{2}=0.929158$, may imply that the specification tests go wrong. Generally, it can be said that the first assumption of the classical linear regression model is satisfied.

The second assumption, the error term has a zero-average value, provided that estimation of coefficients by means of OLS method is satisfied since one of the features of parameter estimation using OLS method is the zero-average value of the residual component, i.e. the error term (Cipra, 2013). The second assumption is satisfied as well.

Since the paired correlation coefficient of the residual (error term) and independent variables is zero, based on the results of the statistical software Gretl. The third assumption, the independent variables are not correlated with the error term, is satisfied.

The fourth assumption, i.e. non-existence of the error term autocorrelation, is understood as the dependence between the sequence of values of one variable over time, not as the dependence between two or more variables. Since the model works with cross-sectional data, i.e. there are no variables developing over time, it is not necessary to test the resultant model for the fourth assumption, which is only considered in the case of timeline modelling (Hušek, 2007).

The fifth assumption, i.e. constant variance requirement (homoscedasticity), can be verified using the White test and Breusch-Pagan test. Hypotheses for both tests are formulated, according to Hušek (2007), as follows: $H_{0}=$ homoscedasticity, $H_{1}=$ heteroscedasticity. In the case of White test, the result is p-value $=0.101436$, the resultant $\mathrm{p}$-value of BreuschPagan test is the p-value $=0.509328$. Both tests of the resultant model have the p-value higher than the selected significance level $=0.05$, so we do not reject the null hypothesis about homoscedasticity. This assumption is consequently satisfied as well.

The last of the assumptions, which remains to be verified, is the normality of residuals since the issue of collinearity in independent variables was initially excluded. So, the sixth assumption is also satisfied. For normality testing, according to Soltes (2018), it is possible to use a wide range of tests, e.g. Chi-square test, Doornik-Hansen test, Shapiro-Wilk W-test or Jarque-Bery test. Even here, the null hypothesis is formulated positively, therefore: $H_{0}=$ residuals are distributed normally, $H_{1}=$ residuals are not distributed normally. Resultant p-values should take values higher than $\alpha=0.05$.

Table 4: Residual normality test of the linear regression model

\begin{tabular}{|ll|}
\hline Residual normality test & p-value \\
\hline Chi-Square test & 0.03451 \\
Doornik-Hansen test & 0.03450 \\
Shapiro-Wilk W-test & 0.01051 \\
Jarque-Bery test & 0.10149 \\
\hline
\end{tabular}

Source: Gretl, own calculation 
However, the results from Chi-Square, Doornik-Hansen and Shapiro-Wilk W-tests reject the normality since the p-values in these tests are lower than the selected significance level $\alpha=0.05$. The reality follows again from a small amount of data where one extreme value results in rejection of the null hypothesis (Cipra, 2013). The main condition for satisfaction of this assumption is the validity of t-tests of model parameters, but also the F-test for overall argumentativeness of the model, which holds true in this case, since the p-value of all independent variables $\left(\beta_{0}=1.22 e^{-05}, \beta_{1}=6.64 e^{-07}, \beta_{2}=7.29 e^{-05}, \beta_{3}=0.0067\right)$ in the model with the 2 nd degree polynomial is lower than the selected significance level $\alpha=0.05$, much like the $\mathrm{p}$-value $\left(p=5.03 e^{-23}\right)$ of overall significance of the model. Consequently, also the seventh assumption of the classical linear regression model can be considered as satisfied.

The resultant model with the 2 nd degree polynomial was successfully verified both statistically and econometrically, thus the estimation of parameters $\left(\beta_{0}=8369.13, \beta_{1}=-3954.8\right.$, $\beta_{2}=848.59, \beta_{3}=16.39$ ) by OLS method can be considered as the best possible.

\section{Results}

By means of the defined statistical methods and tools for verification of resultant regression equation (1) it is stated that the selected regression model is the best possible. Before we accede to interpretation of the model parameters, it is necessary to verify this model economically. For verification, we use model examples of the trucks presented in Annex 2 to this paper. For model examples it is necessary to state that in terms of taxation of trucks there is no difference between trailer, truck or semi-trailer because the same road tax rates are applicable to all vehicles and all of the vehicles are considered as individual vehicles from the perspective of taxation.

\section{Economic verification of the variable $X_{1}$}

The two-axle truck with the weight of 8 tons (vehicle No. 4), is connected to one-axle trailer with the same permissible maximum weight (vehicle No. 3), but their tax rates per ton are different. The operator is obliged to pay a higher rate per ton in the case of trailer, specifically the tax rate is $1158.62 \mathrm{CZK} / \mathrm{t}$, in the case of truck, the tax rate is lower by $165.52 \mathrm{CZK} / \mathrm{t}$ and it is $993.10 \mathrm{CZK} / \mathrm{t}$. The same applies to the amount of overall taxation of these vehicles, i.e. the one-axle vehicle is taxed by a higher tax rate than the vehicle of the same weight with higher number of axles. Similarly, this truck whose tax rate is $993.10 \mathrm{CZK} / \mathrm{t}$ will be taxed more per unit of permissible maximum weight than the three-axle truck with the same permissible maximum weight 8 tons (vehicle No. 6) whose rate per ton is $827.59 \mathrm{CZK} / \mathrm{t}$. The above mentioned holds true also in the case of towing vehicles, namely when the towing vehicle with the permissible maximum weight 16 tons pays a lower road tax in the case of higher number of axles, both in the case of rate per ton and overall annual tax rate, than the towing vehicle with the same permissible maximum weight and lower number of axles. Particularly, the towing vehicle with permissible maximum weight 16 tons and two axles (vehicle No. 7), towing a threeaxle trailer with the same permissible maximum weight (vehicle No. 10), is taxed by the 
rate per ton in the amount of $1146.36 \mathrm{CZK} / \mathrm{t}$, which is more again in comparison with the amount of the tax rate for semi-trailer, which is $825 \mathrm{CZK} / \mathrm{t}$. In terms of overall amount of the annual tax rate, the amount is $700 \mathrm{CZK}$ in the case of towing vehicle or $13200 \mathrm{CZK}$ in the case of semi-trailer.

Currently fixed annual road tax rates mean that bigger vehicles, from the perspective of a number of axles, pay lower road tax than those with permissible maximum weight, but with a lower number of axles. The above mentioned corresponds with the negative sign for the number of axles parameter, i.e. the variable $X_{1}$, in regression equation (1) and confirms the degressivity of tax rates owing to number of axles, which is intended to support trucks, towing vehicles, semi-trailers and trailers with higher number of axles with the same weight. The result is the harmony between determination of road tax rate in the Czech Republic and the priority of the Ministry of Transport of the Czech Republic according to Váchal (2018), which consists in pressure on operation of multi-axle trucks with the same vehicle weight. Because these trucks are more friendly from the perspective of infrastructure wear and tear. The Czech Republic is not an exception in comparison with the mentioned countries and it favours the selected vehicles that are more friendly from the perspective of infrastructure wear and tear. However, it does not go the way of different road tax rates for vehicles with pneumatic/air suspension and the other vehicles, but by favouring the multi-axle trucks in the form of a lower road tax rate.

The result is in the form of comparison of the taxation of model vehicles, as it emerges from the above mentioned, it corresponds, in light of the variable $X_{1}$, with the resultant regression model. The independent variable $X_{1}$ was economically verified with success.

\section{Economic verification of the variable $X_{2}$}

For economic verification of the independent variable $X_{2}$ and namely for better visualisation of its functional form refer to Figure 3 . The independent variable $X_{2}$ is plotted on $X$-axis and the dependent variable on $Y$-axis. Points in Figure 3 represent the median of the given weights range and the tax rate appertained to it.

The curve visible in (Figure 3), for the purposes of economic verification of the variable $X_{2}$, will be halved by an imaginary perpendicular to $x$-axis. This imaginary perpendicular intersects the $x$-axis at a distance of 12 units ( 12 tons) from the origin. The reason for this division is given by different development of overall tax rates and the rates per ton for vehicles with the weight up to 12 tons and those with the weight above 12 tons, which is described in paragraphs below and results from Annex 1.

The one-axle vehicles include e.g. trailers, they are considered as separate vehicles liable to tax as per $\S 1$ sect. 1 Road Tax Act even though they are attached to a truck or a towing vehicle. The one axle trailer with permissible maximum weight 3 tons (vehicle No. 1) is taxed by annual tax rate $1418.18 \mathrm{CZK} / \mathrm{t}$, which is a higher tax rate in comparison with the trailer having the same number of axles, but with a permissible maximum weight of 8 tons (vehicle No. 3) whose amount of its annual tax rate is $1158.62 \mathrm{CZK} / \mathrm{t}$. From the perspective of tax per ton, the vehicle with the same number of axles and higher weight is taxed less in this case. However, the amount of overall taxation for these vehicles develops the other way around. The one-axle trailer with the weight of 3 tons is taxed by $3900 \mathrm{CZK}$, 
whereas the trailer with the same number of axles but with the weight of 8 tons is taxed by total of $8400 \mathrm{CZK}$, i.e. by a higher tax rate. The same result can be achieved by comparing the taxation of a two-axle truck with a permissible maximum weight of 8 tons (vehicle No. 4) and 12 tons (vehicle No. 5) whose rate per ton is $993.10 \mathrm{CZK}$, or 939.13 CZK. In both cases, the vehicle with permissible maximum weight is taxed less per ton. In light of total tax, it is quite the opposite. This development of tax rates corresponds with the first part of the curve in Figure 3 because these are the vehicles with permissible maximum weight lower than 12 tons. For these vehicles, the increase in permissible maximum weight results in the increase in overall annual tax rate, so the development of rate per ton is contradictory, i.e. the increase in permissible maximum weight results in the decrease in rate per ton.

Figure 3: Graph of dependent variable $Y$ and independent variable $X_{2}$

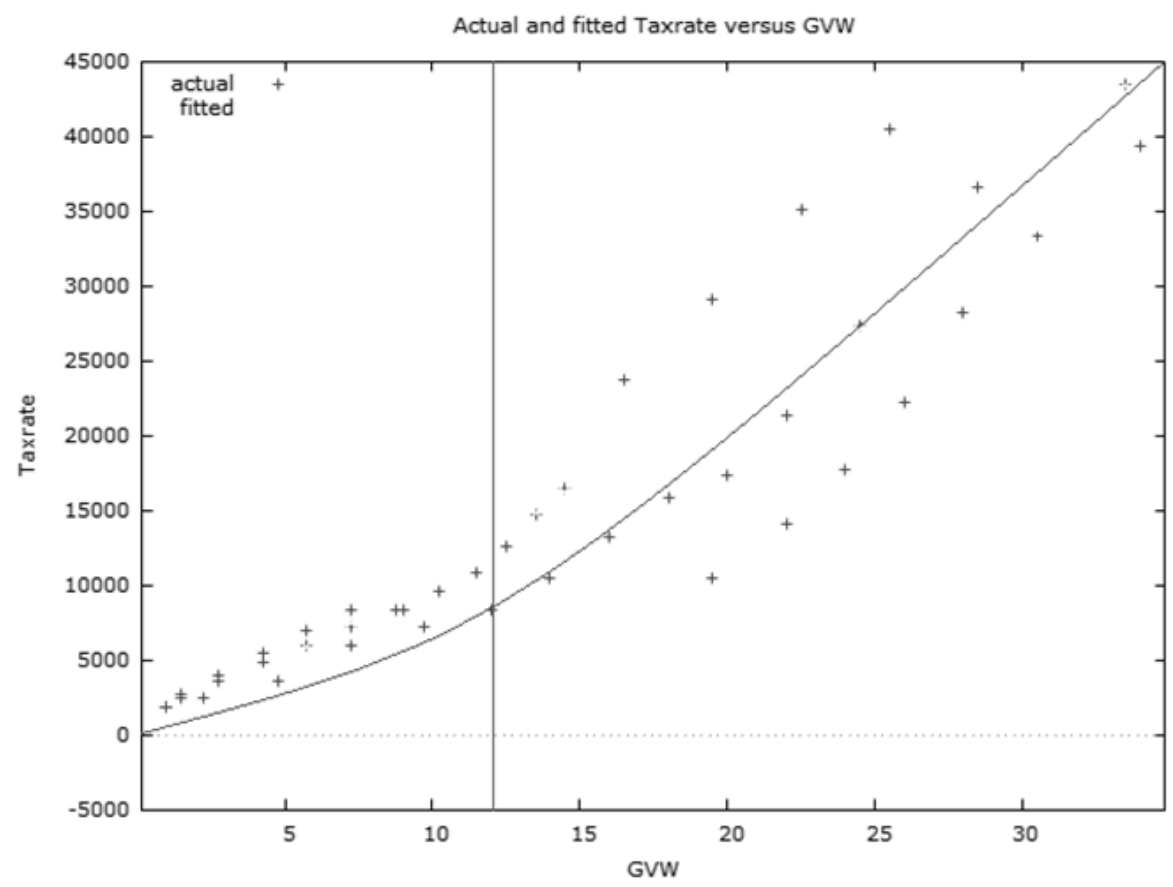

Source: Gretl, own calculation

For two-axle vehicles, an opposite result can be achieved namely when with the maximum permissible vehicle weight, both total annual road tax rate and rate per ton are higher. Again, it is a 12-ton truck (vehicle No. 4), which is taxed by $939.13 \mathrm{CZK} / \mathrm{t}$, or by $10800 \mathrm{CZK}$ in light of overall taxation and the two-axle towing vehicle, but with the weight of 16 tons (vehicle No. 7), which was taxed by $1436.36 \mathrm{CZK} / \mathrm{t}$ or by $23700 \mathrm{CZK}$. The same tax rate development can be observed in vehicles with four axles or in multi-axle vehicles. 
Vehicle No. 9 has the permissible maximum weight of 16 tons, which corresponds to rate per ton amounting to $466.67 \mathrm{CZK}$, vehicle No. 11 has the permissible maximum weight of 24 tons, which corresponds to rate per ton amounting to $737.50 \mathrm{CZK}$, i.e. higher tax rate. In both above given cases, it holds true that the vehicles with the same number of axles are taxed more with increasing weight per unit of weight, but also globally. In this case, these are vehicles with the permissible maximum weight higher than 12 tons.

In both above given comparisons, the vehicles with the same number of axles are taxed with the increasing weight more from the perspective of annual tax rate. The same result was achieved in the linear regression model with the 2 nd degree polynomial since the signs of the permissible maximum weight parameter in the linear regression equation are positive. The overall annual tax rate increases with the increase in permissible maximum weight at the same number of axles. In this context, it is possible to talk only about the direction of dependence, not about the resultant annual tax rate because it is necessary to take the number of axles variable into account.

The development of rates per ton is very interesting; it can be seen in Annex 1, at first the rates are decreasing and then increasing within the groups according to number of axles. The exception is the group of one-axle vehicles where rates per ton are only decreasing and, on the contrary, the rates in the group of 4-axle and multiple axle vehicles are only increasing. It appears from the above given that with lower weight of vehicle, the increase in the maximum permissible vehicle weight is in the lead by a unit against the increase in annual tax rate by less than this unit. The result is the increase in overall road tax rate, but the decrease in rate per ton. Such a development of rates can be observed in vehicles whose permissible maximum weight is approx. 12 tons or lower (first part of the imaginarily divided curve in Figure 3 ). In vehicles with permissible maximum weight higher than 12 tons, the increase in permissible maximum weight is in the lead by a unit, against the increase in rate more than by this unit. The result is not only the increase in overall road tax rate, but also in rate per ton. The relation between the vehicle weight and the annual tax rate amount corresponds to the functional form in the form of the 2 nd degree polynomial, alias parabola. The mentioned regression model arrived at the same result.

In addition to statistical and economic verification (tests), the linear regression model with the 2nd degree polynomial was verified also economically, so it can be said that it corresponds to the simplified reality and it is suitable for interpretation.

Annual road tax rates whose amount was described by the above-mentioned regression equation (1), have as their task, as stated previously, to support the road trains with a higher number of axles that are more friendly to infrastructure.

Within the following procedure, the correlation analysis will be carried out and paired correlation and partial correlation coefficients will be calculated. Within the correlation analysis, the paired correlation coefficients and the partial correlation coefficients can be used. For calculation of paired correlation coefficients, Gretl statistical software can be used again. This software offers the possibility to display correlation matrix (2) that can be seen below. 


$$
\hat{R}=\left(\begin{array}{ccc}
1 & r_{Y X_{1}} & r_{Y X_{2}} \\
r_{X_{1} Y} & 1 & r_{X_{1} X_{2}} \\
r_{X_{2} Y} & r_{X_{2} X_{1}} & 1
\end{array}\right)=\left(\begin{array}{ccc}
1 & 0.3715 & 0.9235 \\
0.3715 & 1 & 0.6146 \\
0.9235 & 0.6146 & 1
\end{array}\right)
$$

It follows from the correlation matrix that higher dependences between the dependent variable and independent variables are reached by the maximum permissible vehicle weight $\left(r_{Y X_{2}}=0.9235\right)$. For comparison, the paired correlation coefficient of the independent variable, number of axles, and the dependent variable $r_{Y X_{1}}=0.3715$. Particularly worthy of note is the sign of this correlation coefficient, i.e. the correlation coefficient of the dependent variable, annual tax rate, and the independent variable, number of axles, which should be negative pursuant to the results of the regression equation (1). However, the value of correlation coefficient may be affected by dependence of another independent variable, which can be verified by calculation of partial correlation coefficients. The calculation of these coefficients is not available in Gretl software and so it is necessary to use the formulas defined in publications, Hušek (2007) or Hendl (2015).

$$
\begin{aligned}
& r_{Y X_{1} \cdot X_{2}}=\frac{0.3715-0.9235 * 0.6146}{\sqrt{\left(1-0.9235^{2}\right) *\left(1-0.6146^{2}\right)}}=-2.14 \\
& r_{Y X_{2} \cdot X_{1}}=\frac{0.9235-0.3715 * 0.6146}{\sqrt{\left(1-0.3715^{2}\right) *\left(1-0.6146^{2}\right)}}=1.29
\end{aligned}
$$

Based on the above given results of partial correlation coefficients, it can be stated that the variable $X_{2}$ of variable $Y$ and $X_{1}$ affect the annual tax rate most because the difference between the paired correlation coefficient $r_{Y X_{1}}(r=0.3715)$ and the partial correlation coefficient $r_{Y X_{1} \cdot X_{2}}(r=-2.14)$ is maximal. The above mentioned explains why the paired correlation coefficient $r_{Y X_{1}}$ is positive. Conversely, the variable $X_{1}$ of variable $Y$ and $X_{2}$ affects the annual tax rate at the least because the difference between the paired correlation coefficient $r_{Y X_{2}}(r=0.9235)$ and the partial correlation coefficient $r_{Y X_{2} \cdot X_{1}}(r=1.29)$ is minimal.

\section{Conclusion}

The current system of truck taxation in the Czech Republic, where the annual road tax rates, whose amounts are expressed by the above-mentioned regression equation (1), supports trucks with a larger number of axles, which are more environment-friendly to the transport infrastructure. The Czech Republic is not an exception within the European countries mentioned in the Introduction and favours trucks that are more sensitive to the infrastructure wear. What differs is the form, which has no direct relation to the type of vehicle suspension. It was stated above that the concept of road tax is similar to tax on benefit, which is one of the fair taxation approaches, according to Musgrave and Musgrave (1994). In the view of Stiglitz (1997) it is fair to contribute towards public expenditure by 
an amount corresponding to the benefit gained from the consumption of public goods and transfers. However, the taxation based on the benefit principle faces two serious issues: one being the ability to measure the benefit and the other being the redistribution function. The high demands of measuring the taxpayer's benefit ensuing from public goods and transfers result in the constant "price" of such public goods (Široký, 2003) or (Jackson, Brown, 2003). Although it is very difficult to determine the marginal benefit ensuing from public goods, it is fair to set the road tax per ton of the permissible maximum weight at the same amount for all trucks. The current road tax rates applicable in the Czech Republic are therefore not only degressive with regard to the number of axles, but also unfair from the viewpoint of tax theory. In order to eliminate tax degression and to establish tax fairness, the road tax rate for trucks should be set at an identical amount per ton of their weight. Such solution would cancel the weight bands and categories based on the number of axles. The elimination of the identified degressivity was evaluated within the performed economic verification using model examples of vehicles defined in the appendix to the paper.

This solution has also been confirmed by the results of the multidimensional regression analysis and correlation analysis, from which it can be concluded that if the degressivity of road tax rates in the Czech Republic was to be eliminated, it would be necessary to adjust the determination of annual road tax rates in such way that it would only use the variable of maximum permissible weight, i.e. a model that would not consider the variable consisting in the number of axles. The performed measurements and verifications proved the degressive nature of annual road tax rates, which, according to the current ART, are based on the number of axles. However, such adjustment to Section 6 (2) ART would lead to restricted support for multi-axle trucks, which are more sensitive to the transport infrastructure. Such road tax model is applied in Ireland and Austria, where the road tax is determined only on the basis of the truck weight, as well as in Lithuania, where it is the weight and the type of suspension that are taken into account. The Czech Republic could apply the feature of eco-friendliness with regard to the infrastructure similarly to the Lithuanian model, i.e. privilege high-quality suspension systems of trucks. The situation is similar in Hungary with the taxation of each $100 \mathrm{~kg}$ of the truck weight or net weight and $50 \%$ of the weight of a loaded vehicle. In Germany, similarly to Hungary, trucks are subject to tax for each $200 \mathrm{~kg}$ of permissible maximum weight; tax rates are further distinguished by emission classes. The last examined country is Austria, where trucks are subject to tax per ton of the total weight of a vehicle.

In sum, considering the results achieved from the performed testing within the paper and the subsequent verification of conclusions achieved, it can be stated that there are tools that lead to the elimination of the currently identified degressivity of the road tax in relation to the number of axles. This degressivity of the road tax causes the required preference of trucks with a higher number of axles that are more friendly to the transport infrastructure, and simultaneously, it may have implications for economic operators' decision-making when choosing the type of truck. However, the proposed solution of removing the axle count element from the road tax rate construction is not in contradiction with the required preference of lorries with a higher number of axles at the time of the introduction of the suspension type element that was defined above. 


\section{Acknowledgments}

This paper was supported by the Technology Agency of the Czech Republic - TACR Environment of life 3, SS03010156.

\section{References}

ACEA (2019). ACEA Tax Guide 2019. [online]. Retrieved from https://www.acea.be/uploads/news_documents/ACEA_Tax_Guide_2019.pdf.

Andrlík, B., Ptáčková Mísařová, P., Vrtalová, J. (2014). Preparedness of the Czech Republic for taxation of road motor vehicles based on CO2. Procedia Economics and Finance, 12(1), $10-19$.

Borger, B, Mayeres, I. (2007). Optimal Taxation of Car Ownership, Car Use and Public Transport: Insights Derived from a Discrete Choice Numerical Optimization Model. Europena Economic Review, 51(5), 1177-1204.

Cipra, T. (2013). Financial Econometrics. Praha: Ekopress.

Cnossen, S. (2005). Theory and Practise of Excise Taxation: Smoking, Drinking, Gambling, Poluting and Driving. Oxford: Oxford University Press.

David, P., Andrlík, B. (2020). Fiskální nástroje v silniční dopravě z environmentálního hlediska. Brno: Akademické nakladatelství CERM s.r.o. ISBN 978-80-7623-040-8.

Delucchi, M. A. (2003). Environmental externalities of motor vehicle use. In: Hensher, D. A., Kenneth J. B.: Handbook of transport and the environment. Oxford: Elsevier.

Hendl, J. (2015). Survey of Statistical Methods. Praha: Portal.

Hindls, R. et al. (2007). Statistics for Economists. Praha: Professional Publishing.

Hušek, R. (2007). Econometric Analysis. Praha: Oeconomica.

Jackson, P. M., Brown, C. W. (2003). Public Sector Economics. Praha: Eurolex.

Kubátová, K. (2015). Tax Theory and Politics. Praha: Wolters Kluwer.

Marková, H. (2019). Tax Laws 2019, Full Texts as of 1 January 2019. Praha: Grada Publishing.

Musgrave, R. A., Musgrave, P. B. (1994). Public Finance in Theory and Practice. Praha: Management Press.

OECD (2016). Consumption Tax Trends 2016: VAT/GST and excise rates, trends and policy issues. [online]. Retrieved from https://read.oecd-ilibrary.org/taxation/consumption-taxtrends-2016_ctt-2016-en\#page1.

Schultzová, A. (2018). Taxation Tax Theory and Politics I. Bratislava: Wolters Kluwer.

Široký, J. (2003). Tax Theory with Practical Application. Praha: C. H. Beck.

Široký, J. (2008). Tax Theory with Practical Application. Praha: C. H. Beck.

Smith, A. (1958). Treatise on the Nature and Origin of the Wealth of Nations. Praha: SNPL

Soltes, E. (2018). Statistical Methods for Economists. Bratislava: Wolters Kluwer.

Stiglitz, J. B. (1997). Public Sector Economics. Praha: Grada publishing.

Štreimikiené, D. (2015). Impact of environmental taxes on sustainable energy development in Baltic states, Czech Republic and Slovakia. E\&M Ekonomie a Management, 18(4), 4-23. 
Štreimikienė, D., Ališauskaitė-Šeškienė, I. (2016). Comparative assessment of external costs and pollution taxes in Baltic states, Czech Republic and Slovakia. E\&M Ekonomie a Management, 19(4), 4-18.

Váchal, A. (2018). Tok has polluted out against the trucks and wants to force them to drive less. Carriers say it will make their services more. [online]. Retrieved from https://archiv. ihned.cz/c1-66189030-tok-vytahl-proti-kamionum-a-chce-je-donutit-vozit-mensi-naklady-dopravci-tvrdi-ze-to-zdrazi-jejich-sluzby.

Vančurová, A., Láchová, L., Vítková, J. (2016). Tax System of the Czech Republic 2016. Praha: 1. VOX.

Zimmermannová, J. (2016). Environmental Taxation and its Impact Modeling. Praha: Wolters Kluwer. 


\section{Appendix}

Annex 1: Calculation of rate per ton of permissible maximum weight of the vehicle for annual taxes under the ART

\begin{tabular}{|c|c|c|c|c|c|}
\hline \multirow{2}{*}{$\begin{array}{l}\text { Number } \\
\text { of axles }\end{array}$} & \multicolumn{2}{|c|}{ Permissible maximum weight $(t)$} & \multirow{2}{*}{$\begin{array}{c}\text { Tax rate } \\
(\mathrm{CZK})\end{array}$} & \multirow{2}{*}{ Median } & \multirow{2}{*}{$\begin{array}{l}\text { Rate per ton } \\
\quad(\mathrm{CZK})\end{array}$} \\
\hline & from & to & & & \\
\hline \multirow[t]{7}{*}{1} & & 1.0 & 1800 & 1.00 & 1800.00 \\
\hline & 1.0 & 2.0 & 2700 & 1.50 & 1800.00 \\
\hline & 2.0 & 3.5 & 3900 & 2.75 & 1418.18 \\
\hline & 3.5 & 5.0 & 5400 & 4.25 & 1270.59 \\
\hline & 5.0 & 6.5 & 6900 & 5.75 & 1200.00 \\
\hline & 6.5 & 8.0 & 8400 & 7.25 & 1158.62 \\
\hline & 8.0 & - & 9600 & - & - \\
\hline \multirow[t]{17}{*}{2} & - & 1.0 & 1800 & 1.00 & 1800.00 \\
\hline & 1.0 & 2.0 & 2400 & 1.50 & 1600.00 \\
\hline & 2.0 & 3.5 & 3600 & 2.75 & 1309.09 \\
\hline & 3.5 & 5.0 & 4800 & 4.25 & 1129.41 \\
\hline & 5.0 & 6.5 & 6000 & 5.75 & 1043.48 \\
\hline & 6.5 & 8.0 & 7200 & 7.25 & 993.10 \\
\hline & 8.0 & 9.5 & 8400 & 8.75 & 960.00 \\
\hline & 9.5 & 11 & 9600 & 10.25 & 936.59 \\
\hline & 11 & 12 & 10800 & 11.50 & 939.13 \\
\hline & 12 & 13 & 12600 & 12.50 & 1008.00 \\
\hline & 13 & 14 & 14700 & 13.50 & 1088.89 \\
\hline & 14 & 15 & 16500 & 14.50 & 1137.93 \\
\hline & 15 & 18 & 23700 & 16.50 & 1436.36 \\
\hline & 18 & 21 & 29100 & 19.50 & 1492.31 \\
\hline & 21 & 24 & 35100 & 22.50 & 1560.00 \\
\hline & 24 & 27 & 40500 & 25.50 & 1588.24 \\
\hline & 27 & - & 46200 & - & - \\
\hline \multirow[t]{4}{*}{3} & - & 1.0 & 1800 & 1.00 & 1800.00 \\
\hline & 1.0 & 3.5 & 2400 & 2.25 & 1066.67 \\
\hline & 3.5 & 6.0 & 3600 & 4.75 & 757.89 \\
\hline & 6.0 & 8.5 & 6000 & 7.25 & 827.59 \\
\hline
\end{tabular}




\begin{tabular}{|c|c|c|c|c|c|}
\hline \multirow{2}{*}{$\begin{array}{l}\text { Number } \\
\text { of axles }\end{array}$} & \multicolumn{2}{|c|}{ Permissible maximum weight $(t)$} & \multirow{2}{*}{$\begin{array}{l}\text { Tax rate } \\
(\text { CZK) }\end{array}$} & \multirow{2}{*}{ Median } & \multirow{2}{*}{$\begin{array}{l}\text { Rate per ton } \\
\quad(\mathrm{CZK})\end{array}$} \\
\hline & from & to & & & \\
\hline & 8.5 & 11 & 7200 & 9.75 & 738.46 \\
\hline & 11 & 13 & 8400 & 12.00 & 700.00 \\
\hline & 13 & 15 & 10500 & 14.00 & 750.00 \\
\hline & 15 & 17 & 13200 & 16.00 & 825.00 \\
\hline & 17 & 19 & 15900 & 18.00 & 883.33 \\
\hline & 19 & 21 & 17400 & 20.00 & 870.00 \\
\hline & 21 & 23 & 21300 & 22.00 & 968.18 \\
\hline & 23 & 26 & 27300 & 24.50 & 1114.29 \\
\hline & 26 & 31 & 36600 & 28.50 & 1284.21 \\
\hline & 31 & 36 & 43500 & 33.50 & 1298.51 \\
\hline & 36 & - & 50400 & - & - \\
\hline \multirow[t]{9}{*}{4 plus } & - & 18 & 8400 & 9.00 & 466.67 \\
\hline & 18 & 21 & 10500 & 19.50 & 538.46 \\
\hline & 21 & 23 & 14100 & 22.00 & 640.91 \\
\hline & 23 & 25 & 17700 & 24.00 & 737.50 \\
\hline & 25 & 27 & 22200 & 26.00 & 853.85 \\
\hline & 27 & 29 & 28200 & 28.00 & 1007.14 \\
\hline & 29 & 32 & 33300 & 30.50 & 1091.80 \\
\hline & 32 & 36 & 39300 & 34.00 & 1155.88 \\
\hline & 36 & - & 44100 & - & - \\
\hline
\end{tabular}

Note: Calculation of rate per ton of vehicle weight is determined as a ratio of annual tax rate to the median of weight band for the given type of vehicle. 


\section{Annex 2: Model examples of truck based on Annex 1}

* Vehicle No. 1: type: trailer, axle arrangement: 2 x 1, technically permitted / permissible maximum weight $(\mathrm{kg}): 3000 / 3000$, technically permitted / permissible maximum weight $(\mathrm{kg})$ per axle: 3 000/3 000, tax base under Section 5 c) ART: 1 axle +3 tons, annual tax rate under Section 6(2) ART: $3900 \mathrm{CZK}$, annual tax rate per ton: 1418.18 CZK

* Vehicle No. 2: type: trailer, axle arrangement: 2 x 1, technically permitted / permissible maximum weight $(\mathrm{kg}): 6000 / 6000$, technically permitted / permissible maximum weight $(\mathrm{kg})$ per axle: 6 000/6 000, tax base under Section 5 c) ART: 1 axle +6 tons, annual tax rate under Section $6(2)$ ART: $6900 \mathrm{CZK}$, annual tax rate per ton: 1200 CZK

* Vehicle No. 3: type: trailer, axle arrangement: 2 x 1, technically permitted / permissible maximum weight $(\mathrm{kg}): 8$ 000/8 000, technically permitted / permissible maximum weight $(\mathrm{kg})$ per axle: 8 000/8 000, tax base under Section $5 \mathrm{c}$ ) ART: 1 axle +8 tons, annual tax rate under Section 6(2) ART: $8400 \mathrm{CZK}$, annual tax rate per ton: 1 158.62 CZK

* Vehicle No. 4: type: truck, axle arrangement: 4 x 2, technically permitted / permissible maximum weight $(\mathrm{kg}): 8$ 000/8 000, technically permitted / permissible maximum weight (kg) per axle: 4 500/4 500, 3 500/3 500, tax base under Section 5 c) ART: 2 axles +8 tons, annual tax rate under Section 6 (2) ART: $7200 \mathrm{CZK}$, annual tax rate per ton: 993.10 CZK

* Vehicle No. 5: type: truck, axle arrangement: 4 x 2, technically permitted / permissible maximum weight $(\mathrm{kg}): 12$ 000/12 000, technically permitted / permissible maximum weight (kg) per axle: 6 500/6 500, 5 500/5 500, tax base under Section 5 c) ART: 2 axles +12 tons, annual tax rate under Section 6 (2) ART: $10800 \mathrm{CZK}$, annual tax rate per ton: 939.13 CZK

* Vehicle No. 6: type: truck, axle arrangement: 6 x 4, technically permitted / permissible maximum weight $(\mathrm{kg}): 8000 / 8000$, technically permitted / permissible maximum weight (kg) per axle: 3 500/3 500, 2 000/2 000, 2 500/2 500, tax base under Section 5 c) ART: 3 axles +8 tons, annual tax rate under Section 6 (2) ART: 6000 CZK, annual tax rate per ton: $827.59 \mathrm{CZK}$

* Vehicle No. 7: type: tractor unit, axle arrangement: 4 x 2, technically permitted / permissible maximum weight $(\mathrm{kg})$ : 16 000/16 000, technically permitted / permissible maximum weight (kg) per axle: 7 500/7 500, 8 500/8 500, tax base under Section 5 c) ART: 2 axles + 16 tons, annual tax rate under Section 6 (2) ART: 23700 CZK, annual tax rate per ton: $1436.36 \mathrm{CZK}$

* Vehicle No. 8: type: tractor unit, axle arrangement: 6 x 2, technically permitted / permissible maximum weight $(\mathrm{kg})$ : 16 000/16 000, technically permitted / permissible maximum weight $(\mathrm{kg})$ per axle: 6 000/6 000, 3 500/3 500, 6 500/6 500, tax base under Section 5 c) ART: 3 axles + 16 tons, annual tax rate under Section 6 (2) ART: $13200 \mathrm{CZK}$, annual tax rate per ton: 825.00 CZK 
* Vehicle No. 9: type: truck, axle arrangement: 8 x 4, technically permitted / permissible maximum weight $(\mathrm{kg}): 16000 / 16000$, technically permitted / permissible maximum weight (kg) per axle: 5 000/5 000, 3 500/3 500, 3 500/3 500, 4 000/4 000, tax base under Section 5 c) ART: 4 axles + 16 tons, annual tax rate under Section 6 (2) ART: $8400 \mathrm{CZK}$, annual tax rate per ton: $466.67 \mathrm{CZK}$

* Vehicle No. 10: type: semi-trailer, axle arrangement: 6 x 2, technically permitted / permissible maximum weight $(\mathrm{kg}): 16000 / 16000$, technically permitted / permissible maximum weight $(\mathrm{kg})$ per axle: 8 000/8 000, 3 500/3 500, 4 500/4 500, tax base under Section 5 b) ART: 3 axles + 16 tons, annual tax rate under Section 6 (2) ART: $13200 \mathrm{CZK}$, annual tax rate per ton: 825 CZK

* Vehicle No. 11: type: truck, axle arrangement: $8 \times 2$, technically permitted / permissible maximum weight $(\mathrm{kg}): 24000 / 24000$, technically permitted / permissible maximum weight (kg) per axle: 8 000/8 000, 2 000/2 000, 2 000/2 000, 12 000/12 000, tax base under Section 5 c) ART: 4 axles +24 tons, annual tax rate under Section 6 (2) ART: $17700 \mathrm{CZK}$, annual tax rate per ton: $737.50 \mathrm{CZK}$ 